\title{
Mixed effects of ecological intensification on natural pest control providers: a short-term study for biotic homogenization in winter wheat fields
}

\author{
Zoltán Elek $^{\text {Corresp., } 1}$, Jana Růžičková ${ }^{1}$, Réka Ádám ${ }^{2}$, Krisztina Bereczki ${ }^{2}$, Gergely Boros ${ }^{3}$, Ferenc Kádár ${ }^{4}$, Anikó \\ Kovács-Hostyánszki ${ }^{2}$, László Somay ${ }^{2,3}$, Ottó Szalkovszki ${ }^{5}$, András Báldi ${ }^{2,3}$ \\ ${ }^{1}$ Eötvös Loránd University, Biological Institute, MTA-ELTE-MTM Ecology Research Group, Budapest, Hungary \\ 2 MTA Centre for Ecological Research, Institute of Ecology and Botany, Lendület Ecosystem Services Research Group, Vácrátót, Hungary \\ 3 GINOP Sustainable Ecosystems Group, MTA Centre for Ecological Research, Tihany, Hungary \\ 4 Plant Protection Institute, Hungarian Academy of Sciences, Centre for Agricultural Research, Budapest, Hungary \\ 5 Department of Botany, National Biodiversity and Gene Conservation Center, Tápiószele, Hungary \\ Corresponding Author: Zoltán Elek \\ Email address: zoltan.elek2@gmail.com
}

Agricultural intensification is one of the major drivers of biotic homogenization and has multiple levels ranging from within-field management intensity to landscape-scale simplification. The enhancement of invertebrate assemblages by establishing new, seminatural habitats, such as set-aside fields can improve biological pest control in adjacent crops, and mitigate the adverse effect of biotic homogenization. In this study we aimed to examine the effects of ecological intensification in winter wheat fields in Hungary. We tested how pests and their natural enemies were affected at different spatial scales by landscape composition (proportion of semi-natural habitats in the surrounding matrix), configuration (presence of adjacent set-aside fields), and local field management practices, such as fertilizer (NPK) applications without applying insecticides. We demonstrated that at the local scale, decreased fertilizer usage had no direct effect either on pests or their natural enemies. Higher landscape complexity and adjacent semi-natural habitats seem to be the major drivers of decreasing aphid abundance, suggesting that these enhanced the predatory insect assemblages. Additionally, the high yield in plots with no adjacent set-aside fields suggests that intensive management can compensate for the lower yields on the extensive plots. Our results demonstrated that although complexity at the landscape scale was crucial for maintaining invertebrate assemblages, divergence in their response to pests and pathogens could also be explained by different dispersal abilities. Although the landscape attributes acted as dispersal filters in the organization of pest and pathogen assemblages in croplands, the presence of set-aside fields negatively influenced aphid abundance due to their between-field isolation effect. 


\section{Mixed effects of ecological intensification on natural pest control}

2 providers: a short-term study for biotic homogenization in winter wheat

\section{3 fields}

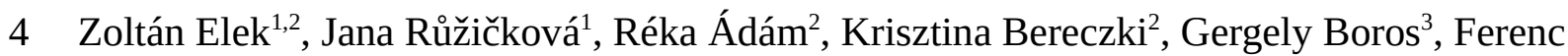

5 Kádár ${ }^{4}$, Anikó Kovács-Hostyánszki², László Somay ${ }^{2,3}$, Ottó Szalkovszki ${ }^{5}$, András Báldi²,3

6

7

8 1- MTA-ELTE-MTM Ecology Research Group, Eötvös Loránd University, Biological Institute,

9 Pázmány Péter sétány 1/C, 1117 Budapest, Hungary

10 2- MTA Centre for Ecological Research, Institute of Ecology and Botany, Lendület Ecosystem

11 Services Research Group, Alkotmány u. 2-4, 2163 Vácrátót, Hungary

$12{ }^{3}$ - MTA Centre for Ecological Research, GINOP Sustainable Ecosystems Group, Klebelsberg K.

13 u. 3, 8237 Tihany, Hungary

14 4- Centre for Agricultural Research, Plant Protection Institute, Hungarian Academy of Sciences,

15 Herman Ottó út 15, 1022 Budapest, Hungary

16 5-Department of Botany, National Biodiversity and Gene Conservation Center, Külsőmezö út 15,

172766 Tápiószele, Hungary

19 Address for correspondence:

20 Zoltán Elek

21 MTA-ELTE-MTM Ecology Research Group, Hungarian Academy of Sciences, c/o Biological

22 Institute, Eötvös Loránd University, Pázmány Péter sétány 1/C, 1117 Budapest, and Hungarian

23 Natural History Museum, Baross u. 13, 1088 Budapest, Hungary

24 e-mail: zoltan.elek2@gmail.com, tel.: +36305874787 
25 Abstract

26 Agricultural intensification is one of the major drivers of biotic homogenization and has multiple

27 levels ranging from within-field management intensity to landscape-scale simplification. The

28 enhancement of invertebrate assemblages by establishing new, semi-natural habitats, such as set-

29 aside fields can improve biological pest control in adjacent crops, and mitigate the adverse effect

30 of biotic homogenization. In this study we aimed to examine the effects of ecological

31 intensification in winter wheat fields in Hungary. We tested how pests and their natural enemies

32 were affected at different spatial scales by landscape composition (proportion of semi-natural

33 habitats in the surrounding matrix), configuration (presence of adjacent set-aside fields), and

34 local field management practices, such as fertilizer (NPK) applications without applying

35 insecticides. We demonstrated that at the local scale, decreased fertilizer usage had no direct

36 effect either on pests or their natural enemies. Higher landscape complexity and adjacent semi-

37 natural habitats seem to be the major drivers of decreasing aphid abundance, suggesting that these

38 enhanced the predatory insect assemblages. Additionally, the high yield in plots with no adjacent

39 set-aside fields suggests that intensive management can compensate for the lower yields on the

40 extensive plots. Our results demonstrated that although complexity at the landscape scale was

41 crucial for maintaining invertebrate assemblages, divergence in their response to pests and

42 pathogens could also be explained by different dispersal abilities. Although the landscape

43 attributes acted as dispersal filters in the organization of pest and pathogen assemblages in

44 croplands, the presence of set-aside fields negatively influenced aphid abundance due to their

45 between-field isolation effect.

47 Keywords: aphids; ecosystem services; inorganic fertilizer; pathogens; set-aside field 
50

51

52

53

\section{Introduction}

Landscape simplification has been suspected to influence the local patterns of species richness and abundance, because of the reduced capacity to support large species-pools, and the lack of opportunity for spill-over between different habitats (Tscharntke et al., 2012, Karp et al., 2018, Dainese et al. 2019). Nevertheless, the effects of agricultural intensification (characterized by intensive land use and the vast application of agrochemicals) at different spatial scales have only been partially analyzed (Hendrickx et al., 2007; Gámez-Virués et al., 2015; Gagic et al., 2017). Agricultural intensification may also serve as an ecological filter, simplifying entire communities through the process of biotic homogenization, as well as decreasing the diversity and resilience against the disturbance caused by farm management (Olden et al., 2004; Gámez-Virués et al., 2015; Tscharntke et al., 2016). The simplified arthropod communities might be restricted in their functions, and may result in the deterioration of ecosystem services (Yachi \& Loreau, 1999, Woodcock et al. 2016). Although the environmental filtering of the local habitats and landscape composition may act as a driver for biotic homogenization, their effects on the assemblages of pests and their natural enemies has been rarely explored.

Insect pollinators, natural enemies, and soil decomposers are key factors for production in the various economically important crop systems (Bartomeus, Gagic \& Bommarco, 2015; Klein et al., 2015; Tamburini et al., 2016). These groups provide regulatory ecosystem services (ES), often influenced by field management, landscape composition and configuration (Karp et al., 2018). There is an emerging interest in how agricultural management and external inputs can be combined with, or potentially replaced by ESs to enhance yields (Bommarco, Kleijn \& Potts, 2013; Klein et al., 2015; Marini et al., 2015; Kleijn et al. 2019). Ecological intensification (EI) has been proposed with the aim to exploit the power of ESs in order to sustain agricultural production, while minimizing the adverse effects on the environment, such as the loss of biodiversity or landscape simplification (Kleijn et al., 2019). Although growing evidence 
75 suggests that ecologically intensified farming can safeguard food production and mitigate its

76 adverse effects on the natural environment, the conscious use of ES providers (natural enemies,

77 pollinators, decomposers, etc.) is still scarce (Bommarco, Kleijn \& Potts, 2013; Martin,

78 Reineking, Seo \& Steffan-Dewenter, 2015). For instance, Tamburini et al. (2016) proved that

79 biological pest regulation was influenced by soil management, suggesting that conservation

80 tillage enhances soil fertility and natural pest control. Moreover, geographical bias exists: most of

81 the studies on the relationship between farmland diversity (as a proxy for available ESs) and

82 agricultural management have emerged from Western Europe (Tryjanowski et al., 2011; Sutcliffe

83 et al., 2015) and North America (Kleijn et al., 2019).

$84 \quad$ In this study, we tested whether the enhancement of beneficial invertebrate

85 assemblages, as pest control providers could contribute to the improvement of crop yields

86 through reduced level of management intensity. We also looked for clues whether the number of

87 newly established, semi-natural habitats adjacent to winter wheat fields could act as proxies for

88 EI. We also tested whether fertilizers, as a key part of intensified crop management, interacted

89 with landscape composition and configuration on selected pathogens, aphids and their natural

90 enemies. We hypothesized that (i) a higher proportion of semi-natural habitats in the landscape

91 can mitigate the negative effects of local (intensive) field management practices on the within-

92 field abundance of natural enemies. Thus, enhanced connectivity between the habitat patches

93 might lead to more natural enemies at the landscape level, and (ii) at the between-field scale,

94 winter wheat fields with adjacent set-aside fields would have a higher abundance of natural

95 enemies and enhanced natural pest control. At the plot level, we assumed that (iii) intensive

96 inorganic fertilizer use in poor soils (acidic soil $\mathrm{pH}$ with low soil organic content) would enhance

97 wheat yields, as well as the abundance of pathogens and aphids; while fertilizer usage in good

98 soils (i.e., high soil organic content, neutral $\mathrm{pH}$ ) would not have such an effect. 
Material and methods

101 Experimental area

Our study was conducted in the Heves Plain High Nature Value Area in North-

103 Eastern Hungary. This region is one of the major target areas of agri-environmental schemes in

104 Hungary (Kovács-Hostyánszki, Batáry \& Báldi 2011; Kovács-Hostyánszki \& Báldi 2012). The

105 proportion of croplands in this region was 70\%, the major crops being winter wheat, maize, as

106 well as spring- and winter barley. Other major but less frequently sown crops were oilseed rape,

107 sugar beet and sunflower. We selected 14 experimental winter wheat fields of 5-10 ha (geometric

108 mean =7.071 ha, S.D.=3.53 ha). Seven of these had an adjacent, newly established (1 to 3 years

109 old) set-aside field of sizes between 1.98 to 5.43 ha (geometric mean $=4.102$ ha, S.D. $= \pm 1.65$ ha),

110 while the others, without any adjacent set-aside field, served as controls. The distance between

111 the studied wheat fields was $1.54-10.84 \mathrm{~km}$. The set-aside fields were sown by a seed-mixture,

112 which included one leguminous (i.e., Medicago sativa) and two grass species (i.e., Lolium spp.,

113 Festuca spp.). During the maximum time of the 3-year set-aside management period, the use of

114 agrochemicals was prohibited, and the fields were mown once a year in the second half of June

115 (Kovács-Hostyánszki, Batáry \& Báldi 2011). The owners of these set-aside fields took part in the

116 Hungarian Agri-Environmental Programme (HAEP-NHRDP 2007-13), in which the primary

117 goal was to improve soil fertility and water retention, as well as to increase farmland biodiversity.

118 In 2014, we assigned an experimental plot of $45 \times 20 \mathrm{~m}$ in each of the selected

119 winter wheat field adjacent to the field margin (Fig. 1a). In the wheat fields with adjacent set-

120 aside fields, the plot was at the edge towards the set-aside field. The farmers were asked to avoid

121 applying fertilizers or insecticides within the experimental plots while maintaining all other

122 conventional management practices. To assess the impact of fertilizer application and to avoid

123 any interference between treatments, these areas were subdivided into two plots of $20 \times 20 \mathrm{~m}$,

124 with a $5 \mathrm{~m}$ separation strip between them. One plot was treated with an NPK fertilizer at the usual 
125 rate of $95 \mathrm{~kg} \mathrm{~N} / \mathrm{ha}$ in mid-April 2014, while the other plot received no fertilizer input (fertilizer

126 control, Fig. 1a).

127

128 Soil characterization

129 We collected $15 \mathrm{~cm}$ soil cover to assess the soil organic content (SOC, a proxy for

130 soil fertility) and $\mathrm{pH}$. A total of 15 samples were taken per fertilizer control plots at the $10+$ stage

131 (BBCH scale, Zadoks et al., 1974 ) of the wheat plants in mid-March and were stored at $4^{\circ} \mathrm{C}$.

132 Prior to analysis, samples from each plot were sieved (at $4 \mathrm{~mm}$ mesh size) and blended.

133 Subsequent soil analyses were conducted according to the Hungarian certifications (no. 08-0452

134 and 08-0206-2) and the method described by Mason (1983).

136 Landscape attributes

137 The landscape composition was calculated in a circle with 1000 m-radius around

138 each studied field. The proportion of arable fields, semi-natural habitats (semi-natural grasslands,

139 semi-natural forests, tree lines, hedges and shrubs), urban areas and water bodies were measured

140 using a GIS database (QGIS Development Team, 2018). We considered landscapes with > 20\%

141 semi-natural habitats as structurally complex, while landscapes with $<20 \%$ of such habitats were

142 classified as simple (Batáry et al., 2011; Tscharntke, Batáry \& Dormann, 2011). The

143 presence/absence of set-aside fields adjacent to a study plot indirectly measures the spatial

144 configuration (i.e., frequency of semi-natural habitats in the landscape) of the studied land use

145 categories (Fahrig et al., 2011).

Arthropod and pathogen surveys

The abundance of aphids, their natural enemies and wheat pathogens was assessed

149 by visual plant surveys in each plot along two parallel transects perpendicular to the margin, $5 \mathrm{~m}$ 
150 from each other at 5, 10 and $20 \mathrm{~m}$ from the edge of the wheat fields adjacent to the set-aside field,

151 which were towards the habitat core. We randomly selected 17 wheat tillers per transect per

152 distance $(17 \times 2 \times 3=102$ tillers per plot, Fig. $1 b)$, and on each of these, we counted the number

153 of grain aphids (mostly Sitobion avenae, Hemiptera: Aphidoidea), coccinellid adults and larvae

154 (Coleoptera: Coccinellidae), syrphid larvae (Diptera: Syrphoidea), chrysopid larvae (Neuroptera:

155 Chrysophidae), and the number of parasitized aphids (including mummies). We also visually

156 assessed the major pathogens, including leaf spots (Septoria spp., Fusarium spp.), mildew and

157 rust (Puccinia spp.) on the leaves. Plant surveys were conducted on three occasions in April

158 (stem elongation stage; BBCH 35), May (head-forming stage; BBCH 50) and June (flowering

159 stage; $\mathrm{BBCH} 60)$.

To monitor the activity density (a proxy for abundance from pitfall trap data,

161 hereafter referred as 'abundance') of the surface-active natural enemies, four pitfall traps were

162 installed along the transects (Fig. 1b) in each experimental (i.e,. fertilized and control) plot and

163 operated for two weeks in late May - early June. The traps consisted of plastic cups of 114 mm

164 diameter, each of which filled with approximately $250 \mathrm{ml}$ of a $50 \%$ propylene glycol solution

165 saturated with $\mathrm{NaCl}$ and a drop of odorless detergent to reduce the surface tension. A green

166 plastic roof protected the traps from litter and rain. The pitfall traps were emptied after 14 days,

167 the catch was sorted in the laboratory, and the abundance of adult ground beetles and cursorial

168 spiders (Lycosidae) was calculated.

169

170 Estimating yield

171

In June, all experimental plots were hand-harvested. Two sub-samples of $0.58 \times$

$1720.58 \mathrm{~m}$ area were taken at each distance $(5,10$ and $20 \mathrm{~m})$, resulting in a harvest sample of $1 \mathrm{~m}^{2}$ in

173 total. Harvested ears were transported in cotton bags and dried at $24^{\circ} \mathrm{C}$ for $48 \mathrm{~h}$ in a climate

174 chamber under 10\% RH. After threshing, we measured the total fresh grain mass per replicate 
175 batch, as well as fresh and dry mass of sub-samples in order to calculate the total grain yield (g/

$176 \mathrm{~m}^{2}$ ) (standardized to a moisture content of 14\%); the grain and the ear mass were used for further 177 analyses.

178

179 Statistical analyses

180

We used linear mixed models to test the responses of pests (aphid abundance),

181 pathogens (prevalence of leaf spots expressed as percentage), natural enemies (abundance of

182 ground beetles and spiders) and winter wheat yields (estimated as mass of wheat- ear and grain)

183 to soil properties, nitrogen use, landscape complexity and configuration. To achieve a normal

184 distribution of the residuals, all response variables were square-root transformed. We created sets

185 of single-argument models on each response variable, to avoid colinearity and maximize the

186 predictive power of explanatory variables, only one explanatory variable was considered in each

187 model (Burnham \& Anderson, 2002). As for explanatory variables, we included soil properties

188 including $\mathrm{pH}$ (continuous variable) and SOC (continuous variable), nitrogen treatment

189 (categorical variable with two levels: fertilizer applied/not applied), presence of adjacent set-

190 aside field (categorical variable with two levels: with/without bordering set-aside field), or

191 landscape complexity (categorical variable with two levels: simple/complex). In all models, the

192 farm ID (nominal variable) was used as a random effect. For these aforementioned models we

193 used the function 'Ime' from the 'nlme' package (Pinheiro et al., 2017). Afterwards, each set of

194 models was tested to select the best ones based on the Akaike Information Criterion (AICc)

195 corrected for small samples sizes (Burnham \& Anderson, 2002) using the model.sel function

196 from the 'MuMIn’ package (Bartoń, 2016). When $\Delta$ AICc $>2$, the 'best approximating’ model

197 was selected as the most parsimonious explanation (see Table 1 for details). When more than one

198 model had $\triangle$ AICc $<2$, we applied a model averaging approach for the uncertainty in model

199 selection and obtained robust parameter estimates (Grueber et al., 2011). During model 
200 averaging, we built all possible models with the given explanatory variables and parameter

201 estimates of the best models ( $\triangle \mathrm{AICc}<2)$, which were fully averaged with the models’ AICc

202 weights. We used the dredge and model.avg functions from the ‘MuMIn’ package for model

203 averaging. All the analyses were compiled in R 3.4.1 (R Core Team, 2019). The datasets collected

204 on different sampling occasions were pooled for analyses. For all analyses, the alpha was set to

2050.05.

206

207 Results

208 Pests and pathogens

209

The presence of adjacent set-aside fields significantly affected aphid abundance.

210 There were significantly more aphids in winter wheat fields without adjacent set-aside fields than

211 in those with set-aside fields (Table 2, Fig 2a). Neither soil properties, nor nitrogen use or

212 landscape complexity affected aphid abundance. We did not find any significant effects of within-

213 and between-field factors on the prevalence of aphids. The prevalence of leaf spots was higher in

214 complex than in simple landscapes (Fig 2b).

215

216 Natural enemies

217

Our results did not indicate significant impact on the abundance of the two

218 studied groups of ground-dwelling predators by any studied factors (Table 2, Fig. 3). However,

219 the model selection procedure revealed that individual models, including $\mathrm{pH}$ and fertilizer

220 treatments, were the two most parsimonious ones to describe the changes in carabid abundance,

221 while those featuring landscape complexity and the presence of adjacent set-aside fields, as well

222 as SOC and fertilizer treatments, were the best models for describing the changes in spider

223 abundance (Table 1). In addition, soil pH had a marginally positive effect on the abundance of

224 ground beetles, suggesting that, on average, slightly more beetles were present in the soil with 
225 neutral $\mathrm{pH}$.

226

227 Yield estimations

228

Ear and grain mass were significantly higher in fields without adjacent set-aside

229 fields (Table 2, Fig 2c, 2d) but no other variable had an impact on yield.

230

231 Discussion

We compared the effects of EI on the relationships between pests and their natural

enemies at different spatial scales, from within- to between-field differences and up to landscape

scale effects. We found that adjacent set-aside fields and landscape complexity seemed to be the

drivers of the reduction in aphid abundance and the prevalence of pathogenic fungi. However,

236 fertilizer use had no direct effect either on pests or their natural enemies.

Landscape influence on pests and pathogens

Agricultural landscapes are not static and may influence disease dynamics not only through its structure but also through its own dynamics (Plantegenest, Le May \& Fabre,

241 2007). We found that the landscape configuration and complexity were key factors in the

242 distribution of pests and pathogens, but the distribution of pathogenic fungi did not support the

243 hypothesis that a higher proportion of semi-natural habitats in the landscape can mitigate the

244 negative effects of local (intensive) field management practices on the within-field abundance of

245 natural enemies, since complex landscapes did not restrict the distribution of pathogens. Although

246 a previous study (Pfender et al., 2006) using a complex air pollution models (CALPUFF)

247 demonstrated that the spores of pathogenic fungi had high deposition within a radius of 1-2 km

248 around their source, the complexity of the landscape could actually lead to a locally higher

249 infection rate due to a decreased air transfer distance of about $0.4 \mathrm{~km}$ (Plantegenest, Le May \& 
250 Fabre, 2007). This finding was similar to our results on the prevalence of leaf spots, which was

251 higher in the plots within the complex landscape. The decreased infection in simple agricultural 252 landscapes could also be explained by the more effective chemical treatments (Plantegenest, Le

253 May \& Fabre, 2007; Gagic et al., 2017). We also demonstrated that the studied ground-dwelling

254 predators seemed to be unaffected by the landscape constrains, leaving our hypothesis (i)

255 unsupported. With regard to carabid beetles, in contrast to a previous study (Cole et al., 2002) we

256 found that local species diversity in agricultural fields did not differ significantly when compared

257 to semi-natural areas, owing to the high turnover of the typical agrobiont species. Our local

258 spider assemblages were enhanced in the patches surrounded by a larger percentage of non-crop

259 habitats, agreeing with earlier results by Clough et al., (2005) and Hendrickx et al. (2007).

260 Additionally, the local communities in landscapes consisting of small and disconnected patches

261 were characterized by a species composition with low beta-diversity. This homogenization caused

262 by agricultural intensification may suggest that local assemblages are becoming more

263 unsaturated, most probably because of the loss of specialist - and typically less competitive -

264 species with low dispersal ability, such as many ground-dwelling predators (Clough et al., 2005,

265 Hendrickx et al., 2007). In addition, highly mobile species could mask the effect of spatial

266 heterogeneity between habitats, as demonstrated on orthopterans by Marini et al. (2011).

268 The beta diversity of natural enemies is masked by their mobility

We observed that less grain aphids were on plots that had adjacent set-aside

270 habitats, while the natural enemies seemed unaffected, thus our hypothesis (ii) was just partially

271 supported. This could be explained by the spillover of natural enemies into crop fields, resulting

272 in better pest control (Woodcock et al., 2016). Any increase in aphid population growth, as well

273 as any increase in aphid suppression with an increase in landscape complexity, could be

274 explained by the higher availability of alternative resources and overwintering habitats in the 
275 semi-natural habitats around crop fields, benefiting both pests and their natural enemies (Martin

276 et al., 2015; Karp et al., 2019). Additionally, the low abundance of aphids in the plots next to set-

277 aside fields suggested that EI is also characterized by the contribution of other natural enemy

278 groups to pest control (e.g., parasitoid wasps; Martin et al., 2015) or the isolation effect by the

279 adjacent non-crop areas (Dainese et al., 2019; Karp et al., 2019).

280

We observed no effect of the presence of an adjacent set-aside field on the

281 abundance of natural enemies. The available evidence (Hendrickx et al., 2007) suggests that the

282 more specialized species (even natural enemies) abandon the isolated habitat patches that,

283 consequently, contain only a few generalist species of high dispersal ability. The lack of response

284 in two groups of natural enemies at the within-field scale might suggest that the intensive,

285 asymmetric species flows (or spillovers) between the fields during the ripening phase of winter

286 wheat masked eventual differences in habitat utilization between croplands and the semi-natural

287 habitats (sensu lato Marini et al., 2011).

Yields: conditions within intensive fields are connected to local land-use traditions

Although we demonstrated no effect of fertilization on the abundance of pests,

291 pathogens or their natural enemies, we found that the grain yield was higher in plots without adjacent set-aside than with them. In addition, the yield remained unaffected by soil pH or SOC. These results partially supported our hypothesis (iii), pointing to below- and above-ground ESs.

294 At the below ground, the unaffected yield by soil parameters might be caused by the increased nitrogen loss rate in calcareous soils and the less efficient $\mathrm{N}$ utilization in the soil with intensive fertilizer application (Ju et al., 2009). A good quality topsoil with high SOC levels and optimal pH supports a healthy soil fauna (Scheu, 2001). A previous study by Petterson et al. (2007) revealed that higher abundance of grain aphids in fields with high SOC could be explained by their sensitivity to any changes in plant quality. Above ground, the observed lack of effect of 
300 fertilizer use on natural enemies, such as spiders and carabids, might imply that high SOC levels

301 and optimal $\mathrm{pH}$ could support the soil fauna, which provides sufficient food for these groups to

302 successfully resist management related disturbances. This may lie behind the marginally positive

303 effect of $\mathrm{pH}$ on carabid abundance.

304 The fact that we did not detect any direct effect of the fertilizer on crop yield

305 might lead to the conclusion that high soil fertility itself was more important than the external

306 inputs. The lack of a relationship between the yield and any soil parameter such as $\mathrm{pH}$ and SOC

307 could also be explained by the fact that while the best soils were farmed by intensive methods,

308 the owners used their less fertile land as set-aside fields. We also found high yields in fields

309 without adjacent set-aside fields. This could be explained by between-site variability in soil

310 properties, which were independent of the proportion of arable land in the landscape, and being

311 masked by intensive management practices (Williams \& Hedlund, 2013; Bartomeus Gagic \&

312 Bommarco 2015; Gagic et al., 2017). Crop yield is influenced by a combination of biotic and

313 abiotic factors. A better understanding of the interactions between above- and below-ground

314 processes and ESs might ensure high crop yields, but this also requires the investigation of how

315 they co-vary within and between crop fields (Gagic et al., 2017; Tamburini et al., 2016).

\section{Conclusions}

319 In conclusion, landscape features such as the presence of set-aside areas were the most important

320 factors in determining the abundance of aphids in our studied cereal fields. We found that the lack

321 of fertilization is not directly beneficial for spiders or ground beetles, suggesting that such

322 extensive farming might not boost these natural enemies, due to the probability of increased

323 between-field isolation caused by high compositional diversity at a landscape scale (Hendrickx et

324 al., 2007; Martin et al., 2015; Tscharntke et al., 2016). Furthermore, our study focused on near- 
325 final ripening phase of the winter wheat, when the activity of natural enemies was the highest in

326 the season, resulting in an equilibrium (equal abundance between croplands and adjacent set-

327 aside fields) in habitat use between croplands, field margins and the set-aside fields (Tscharntke

328 et al., 2012; 2016). Therefore, conserving and enhancing the landscape diversity appears to be the

329 key intervention to optimize the interaction between pests and their natural enemies in this

330 agroecosystem. Our short-term study provided only a snapshot of the complex dynamics of

331 agroecosystems; thus, the detected asymmetric species flows might have masked the differences

332 in habitat utilization by natural enemies. Moreover, our demonstrative results underline the fact

333 that agricultural practices can interfere with the abundance of natural enemies. Several landscape

334 management practices may decrease the abundance of natural enemies and therefore the level of

335 natural pest control. Hence, it is important to utilize evidence-based practices, which may include

336 the reduction in chemical use, and promote natural enemies, as well as pest-specific measures to

337 prevent the expansion of pest populations. Moreover, our results prompted us to conclude that

338 management intensification at the within-field scale was still capable of compensating the yield

339 gap caused by extensive management practices at the between-field scale.

\section{Acknowledgements}

We thank all the farmers who allowed us to work on their land, László Tóth of the

344 Bükk National Park Directorate for his help in the selection of the field sites as well as providing

345 help during the study, Dorottya Molnár for field assistance, and Gábor Lövei for linguistic

346 revision. This study was funded by the EU FP7-project, LIBERATION (Linking farmland

347 Biodiversity to Ecosystem services for effective ecological intensification; project no. 311781)

348 and the MTA Lendület Program. The analysis and writing of the paper was supported by the

349 GINOP-2.3.2-15-2016-00019 project. 


\section{References}

352 Batáry P, Báldi A, Kleijn D, Tscharntke T. 2011. Landscape-moderated biodiversity effects of

353 agri-environmental management: A meta-analysis. Proceedings of the Royal Society B:

354 Biological Sciences 278:1894-1902. DOI: 10.1098/rspb.2010.1923.

355 Bartomeus I, Gagic V, Bommarco R. 2015. Pollinators, pests and soil properties interactively

356 shape oilseed rape yield. Basic and Applied Ecology 16:737-745. DOI:

$357 \quad$ 10.1016/j.baae.2015.07.004.

358 Bartoń K. 2016. MuMIn: Multi-Model Inference. https://CRAN.R-project.org/package=MuMIn

$359 \quad$ [accessed 04 September 2019].

360 Bommarco R, Kleijn D, Potts SG. 2013. Ecological intensification: harnessing ecosystem

361 services for food security. Trends in Ecology \& Evolution 28:230-8. DOI:

$362 \quad$ 10.1016/j.tree.2012.10.012.

363 Burnham KP, Anderson DR. 2002. Model Selection and Multimodel Inference: a Practical

364 Information Theoretic Approach. Springer-Verlag, New York, USA. ISBN: 0-387-95364-7.

365 Clough Y, Kruess A, Kleijn D, Tscharntke T. 2005. Spider diversity in cereal fields: Comparing

366 factors at local, landscape and regional scales. Journal of Biogeography 32:2007-2014. DOI:

$367 \quad$ 10.1111/j.1365-2699.2005.01367.x.

368 Cole L, McCracken D, Dennis P, Downie I, Griffin A, Foster G, Murphy K, Waterhouse T. 2002.

369 Relationships between agricultural management and ecological groups of ground beetles

370 (Coleoptera : Carabidae) on Scottish farmland. Agriculture, Ecosystems \& Environment

371 93:323-336 DOI: 10.1016/S0167-8809(01)00333-4.

372 Dainese M, Martin EA, Aizen MA, Albrecht M, Bartomeus I, Bommarco R, Carvalheiro LG,

373 Chaplin-kramer R, Gagic V, Garibaldi LA, Ghazoul J, Grab H, Jonsson M, Karp DS,

374 Letourneau DK, Marini L, Poveda K, Rader R, Smith HG, Takada MB, Taki H, Tamburini G, 
375 Tschumi M, Viana BF, Westphal C, Willcox BK, Wratten SDSD, Yoshioka A, Zaragoza-

376 Trello C, Zhang W, Zou F, Steffan-Dewenter I, Kennedy CM, Kleijn D, Kremen C, Landis

377 DA, Letourneau DK, Marini L, Poveda K, Rader R, Smith HG, Tscharntke T, Andersson

378 GKS, Badenhausser I, Baensch S, Bezerra ADM, Bianchi FJJA, Boreux V, Bretagnolle V,

379 Caballero-Lopez B, Cavigliasso P, Ćetković A, Chacoff NP, Classen A, Cusser S, da Silva e

380 Silva FD, de Groot GA, Dudenhöffer JH, Ekroos J, Fijen T, Franck P, Freitas BM, Garratt

381 MPD, Gratton C, Hipólito J, Holzschuh A, Hunt L, Iverson AL, Jha S, Keasar T, Kim TN,

382 Kishinevsky M, Klatt BK, Klein A-M, Krewenka KM, Krishnan S, Larsen AE, Lavigne C,

383 Liere H, Maas B, Mallinger RE, Martinez Pachon E, Martínez-Salinas A, Meehan TD,

384 Mitchell MGE, Molina GAR, Nesper M, Nilsson L, O’Rourke ME, Peters MK, Plećaš M,

385 Potts SG, Ramos D de L, Rosenheim JA, Rundlöf M, Rusch A, Sáez A, Scheper J,

386 Schleuning M, Schmack JM, Sciligo AR, Seymour C, Stanley DA, Stewart R, Stout JC,

387 Sutter L, Takada MB, Taki H, Tamburini G, Tschumi M, Viana BF, Westphal C, Willcox BK,

388 Wratten SDSD, Yoshioka A, Zaragoza-Trello C, Zhang W, Zou Y, Steffan-Dewenter I. 2019.

389 A global synthesis reveals biodiversity-mediated benefits for crop production. Science

$390 \quad$ Advances 5:eaax0121. DOI: 10.1126/sciadv.aax0121.

391 Fahrig L, Crist TO, Sirami C, Siriwardena GM, Baudry J, Brotons L, Burel FG, Martin J-L,

392 Fuller RJ. 2011. Functional landscape heterogeneity and animal biodiversity in agricultural

393 landscapes. Ecology Letters 14:101-112. DOI: 10.1111/j.1461-0248.2010.01559.x.

394 Gagic V, Kleijn D, Báldi A, Boros G, Jørgensen H, Elek Z, Garratt M, de Groot G, Hedlund K,

395 Kovács-Hostyánszki A, Marini L, Martin E, Pevere I, Potts S, Redlich S, Senapathi D,

396 Steffan-Dewenter I, Świtek S, Smith H, Takács V, Tryjanowski P, van der Putten W, van Gils

397 S, Bommarco R. 2017. Combined effects of agrochemicals and ecosystem services on crop

398 yield across Europe. Ecology Letters 20:1427-1436. DOI: 10.1111/ele.12850.

399 Gámez-Virués S, Perović DJ, Gossner MM, Börschig C, Blüthgen N, De Jong H, Simons NK, 
400 Klein AM, Krauss J, Maier G, Scherber C, Steckel J, Rothenwöhrer C, Steffan-Dewenter I,

401 Weiner CN, Weisser W, Werner M, Tscharntke T, Westphal C. 2015. Landscape simplification

402 filters species traits and drives biotic homogenization. Nature Communications 6:8568 DOI:

$403 \quad 10.1038 /$ ncomms9568.

404 Grueber CE, Nakagawa S, Laws RJ, Jamieson IG. 2011. Multimodel inference in ecology and 405 evolution: challenges and solutions. Journal of Evolutionary Biology 24:699-711. DOI:

$406 \quad$ 10.1111/j.1420-9101.2010.02210.x.

407 Hendrickx F, Maelfait J-P, Van Wingerden W, Schweiger O, Speelmans M, Aviron S, Augenstein

408 I, Billeter R, Bailey D, Bukacek R, Burel F, Diekötter T, Dirksen J, Herzog F, Liira J,

409 Roubalova M, Vandomme V, Bugter R. 2007. How landscape structure, land-use intensity and

410 habitat diversity affect components of total arthropod diversity in agricultural landscapes.

$411 \quad$ Journal of Applied Ecology 44:340-351. DOI: 10.1111/j.1365-2664.2006.01270.x.

412 Ju XT, Xing GX, Chen XP, Zhang SL, Zhang LJ, Liu XJ, Cui ZL, Yin B, Christie P, Zhu ZL,

413 Zhang FS. 2009. Reducing environmental risk by improving N management in intensive

414 Chinese agricultural systems. Proceedings of the National Academy of Sciences of the United

415 States of America 106:3041-3046. DOI: 10.1073/pnas.0813417106.

416 Karp DS, Chaplin-Kramer R, Meehan TD, Martin EA, DeClerck F, Grab H, Gratton C, Hunt L,

417 Larsen AE, Martínez-Salinas A, O’Rourke ME, Rusch A, Poveda K, Jonsson M, Rosenheim

418 JA, Schellhorn NA, Tscharntke T, Wratten SD, Zhang W, Iverson AL, Adler LS, Albrecht M,

419 Alignier A, Angelella GM, Anjum MZ, Avelino J, Batáry P, Baveco JM, Bianchi FJJA,

420 Birkhofer K, Bohnenblust EW, Bommarco R, Brewer MJ, Caballero-López B, Carrière Y,

421 Carvalheiro LG, Cayuela L, Centrella M, Ćetković A, Henri DC, Chabert A, Costamagna AC,

422 De la Mora A, de Kraker J, Desneux N, Diehl E, Diekötter T, Dormann CF, Eckberg JO,

423 Entling MH, Fiedler D, Franck P, van Veen FJF, Frank T, Gagic V, Garratt MPD, Getachew A,

424 Gonthier DJ, Goodell PB, Graziosi I, Groves RL, Gurr GM, Hajian-Forooshani Z, Heimpel 
425 GE, Herrmann JD, Huseth AS, Inclán DJ, Ingrao AJ, Iv P, Jacot K, Johnson GA, Jones L,

426 Kaiser M, Kaser JM, Keasar T, Kim TN, Kishinevsky M, Landis DA, Lavandero B, Lavigne

427 C, Le Ralec A, Lemessa D, Letourneau DK, Liere H, Lu Y, Lubin Y, Luttermoser T, Maas B,

428 Mace K, Madeira F, Mader V, Cortesero AM, Marini L, Martinez E, Martinson HM, Menozzi

429 P, Mitchell MGE, Miyashita T, Molina GAR, Molina-Montenegro MA, O’Neal ME,

430 Opatovsky I, Ortiz-Martinez S, Nash M, Östman Ö, Ouin A, Pak D, Paredes D, Parsa S, Parry

431 H, Perez-Alvarez R, Perović DJ, Peterson JA, Petit S, Philpott SM, Plantegenest M, Plećas

432 M, Pluess T, Pons X, Potts SG, Pywell RF, Ragsdale DW, Rand TA, Raymond L, Ricci B,

433 Sargent C, Sarthou JP, Saulais J, Schäckermann J, Schmidt NP, Schneider G, Schüepp C,

434 Sivakoff FS, Smith HG, Whitney KS, Stutz S, Szendrei Z, Takada MB, Taki H, Tamburini G,

435 Thomson LJ, Tricault Y, Tsafack N, Tschumi M, Valantin-Morison M, van Trinh M, van der

436 Werf W, Vierling KT, Werling BP, Wickens JB, Wickens VJ, Woodcock BA, Wyckhuys K,

437 Xiao H, Yasuda M, Yoshioka A, Zou Y. 2018. Crop pests and predators exhibit inconsistent

438 responses to surrounding landscape composition. Proceedings of the National Academy of

439 Sciences of the United States of America 115: E7863-E7870. DOI:

$440 \quad 10.1073 /$ pnas.1800042115.

441 Klein AM, Hendrix SD, Clough Y, Scofield A, Kremen C. 2015. Interacting effects of pollination,

442 water and nutrients on fruit tree performance. Plant Biology 17: 201-208 DOI:

$443 \quad$ 10.1111/plb.12180.

444 Kleijn D, Bommarco R, Fijen TPM, Garibaldi LA, Potts SG, van der Putten WH. 2019.

445 Ecological Intensification: bridging the gap between science and practice. Trends in Ecology

$446 \quad$ and Evolution 34:154-166. DOI: 10.1016/j.tree.2018.11.002.

447 Kovács-Hostyánszki A, Batáry P, Báldi A. 2011. Local and landscape effects on bee communities

448 of Hungarian winter cereal fields. Agricultural and Forest Entomology 13:59-66. DOI:

$449 \quad$ 10.1111/j.1461-9563.2010.00498.x. 
450 Kovács-Hostyánszki A, Báldi A. 2012. Set-aside fields in agri-environment schemes can replace

451 the market-driven abolishment of fallows. Biological Conservation 152:196-203. DOI:

$452 \quad$ 10.1016/j.biocon.2012.03.039.

453 Marini L, Öckinger E, Battisti A, Bommarco R. 2011. High mobility reduces beta-diversity

454 among orthopteran communities - implications for conservation. Insect Conservation and

455 Diversity 5(1):37-45 DOI: 10.1111/j.1752-4598.2011.00152.x.

456 Marini L, Tamburini G, Petrucco-Toffolo E, Lindström SAM, Zanetti F, Mosca G, Bommarco R.

457 2015. Crop management modifies the benefits of insect pollination in oilseed rape.

458 Agriculture, Ecosystems and Environment 207:61-66. DOI: 10.1016/j.agee.2015.03.027.

459 Martin EA, Reineking B, Seo B, Steffan-Dewenter I. 2015. Pest control of aphids depends on

$460 \quad$ landscape complexity and natural enemy interactions. PeerJ 3:e1095. DOI:

$461 \quad$ 10.7717/peerj.1095.

462 Mason BJ. 1983. Preparation of soil sampling protocols: techniques and strategies, EPA-600/4-

463 83-020. Environmental Monitoring and Support Laboratory. U.S. Environmental Protection

464 Agency, Las Vegas, NV 89183-3478; DOI: na.

465 Olden JD, Poff NLR, Douglas MR, Douglas ME, Fausch KD. 2004. Ecological and evolutionary

466 consequences of biotic homogenization. Trends in Ecology and Evolution 19:18-24. DOI:

$467 \quad$ 10.1016/j.tree.2003.09.010.

468 Pettersson J, Tjallingii WF, Hardie J. 2007. Host-plant selection and feeding. In: van Emden H,

469 Harrington R, editors. Aphids as crop pest, vol 4. CAB International, Wallingford 87-113

$470 \quad$ ISBN: 9780851998190.

471 Pfender W, Graw R, Bradley W, Carney M, Maxwell L. 2006. Use of a complex air pollution

472 model to estimate dispersal and deposition of grass stem rust urediniospores at landscape

473 scale. In: Handbook of Environmental Chemistry, Volume 5: Water Pollution 138-153. DOI:

$474 \quad$ 10.1016/j.agrformet.2006.06.007. 
475 Pinheiro J, Bates D, DebRoy S, Sarkar D, R Core Team. 2017. nlme: Linear and nonlinear mixed 476 effects models. https://CRAN.R-project.org/package=nlme [accessed 04 September 2019]. 477 Plantegenest M, Le May C, Fabre F. 2007. Landscape epidemiology of plant diseases. Journal of 478 the Royal Society Interface 4:963-972. DOI: 10.1098/rsif.2007.1114.

479 QGIS Development Team 2018. QGIS Geographic Information System. Open Source Geospatial 480 Foundation. https://qgis.org/en/site/ [accessed 04 September 2019].

481 R Core Team 2019. R: A language and environment for statistical computing. $R$ Foundation for 482 Statistical Computing, Vienna, Austria. https://www.R-project.org [accessed 04 September $4832019]$.

484 Scheu S. 2001. Plants and generalist predators as links between the below-ground and above485 ground system. Basic and Applied Ecology 2:3-13. DOI:10.1078/1439-1791-00031.

Sutcliffe LME, Batáry P, Kormann U, Báldi A, Dicks L V., Herzon I, Kleijn D, Tryjanowski P, 487 Apostolova I, Arlettaz R, Aunins A, Aviron S, Baležentiene L, Fischer C, Halada L, Hartel T, 488 Helm A, Hristov I, Jelaska SD, Kaligarič M, Kamp J, Klimek S, Koorberg P, Kostiuková J, Kovács-Hostyánszki A, Kuemmerle T, Leuschner C, Lindborg R, Loos J, Maccherini S, Marja R, Máthé O, Paulini I, Proença V, Rey-Benayas J, Sans FX, Seifert C, Stalenga J, 493 Timaeus J, Török P, van Swaay C, Viik E, Tscharntke T. 2015. Harnessing the biodiversity value of Central and Eastern European farmland. Diversity and Distributions 21:722-730.

494 Tamburini G, De Simone S, Sigura M, Boscutti F, Marini L. 2016. Soil management shapes 495 ecosystem service provision and trade-offs in agricultural landscapes. Proceedings of the Hromada M, Jerzak L, Kujawa K, Lenda M, Orłowski G, Panek M, Skórka P, Sparks TH, 
500 Tworek S, \& AW, Żmihorski M. 2011. Conservation of Farmland Birds Faces Different

501 Challenges in Western and Central-Eastern Europe. Acta Ornithologica 46:1-12. DOI:

$502 \quad 10.3161 / 000164511 \times 589857$.

503 Tscharntke T, Batáry P, Dormann CF. 2011. Set-aside management: How do succession, sowing

504 patterns and landscape context affect biodiversity? Agriculture, Ecosystems and Environment

505 143:37-44. DOI: 10.1016/j.agee.2010.11.025.

506 Tscharntke T, Karp DS, Chaplin-Kramer R, Batáry P, DeClerck F, Gratton C, Hunt L, Ives A, 507 Jonsson M, Larsen A, Martin EA, Martínez-Salinas A, Meehan TD, O’Rourke M, Poveda K,

508 Rosenheim JA, Rusch A, Schellhorn N, Wanger TC, Wratten S, Zhang W. 2016. When natural

509 habitat fails to enhance biological pest control - Five hypotheses. Biological Conservation

510 204:449-458. DOI: 10.1016/j.biocon.2016.10.001.

511 Tscharntke T, Tylianakis JM, Rand TA, Didham RK, Fahrig L, Batáry P, Bengtsson J, Clough Y,

512 Crist TO, Dormann CF, Ewers RM, Fründ J, Holt RD, Holzschuh A, Klein AM, Kleijn D,

513 Kremen C, Landis DA, Laurance W, Lindenmayer D, Scherber C, Sodhi N, Steffan-Dewenter

514 I, Thies C, van der Putten WH, Westphal C, Batáry P, Bengtsson J, Clough Y, Crist TO,

515 Dormann CF, Ewers RM, Fründ J, Holt RD, Holzschuh A, Klein AM, Kleijn D, Kremen C,

516 Landis DA, Laurance W, Lindenmayer D, Scherber C, Sodhi N, Steffan-Dewenter I, Thies C,

517 van der Putten WH, Westphal C. 2012. Landscape moderation of biodiversity patterns and

518 processes - eight hypotheses. Biological reviews of the Cambridge Philosophical Society

519 87:661-685. DOI: 10.1111/j.1469-185X.2011.00216.x.

520 Williams A, Hedlund K. 2013. Indicators of soil ecosystem services in conventional and organic

521 arable fields along a gradient of landscape heterogeneity in southern Sweden. Applied Soil

522 Ecology 65:1-7. DOI: 10.1016/j.apsoil.2012.12.019.

523 Woodcock BA, Bullock JM, McCracken M, Chapman RE, Ball SL, Edwards ME, Nowakowski

524 M, Pywell RF. 2016. Spill-over of pest control and pollination services into arable crops. 
525 Agriculture, Ecosystems and Environment 231:15-23 DOI: 10.1016/j.agee.2016.06.023.

526 Yachi S, Loreau M. 1999. Biodiversity and ecosystem productivity in a fluctuating environment:

527 The insurance hypothesis. Proceedings of the National Academy of Sciences of the United

528 States of America 96:1463-1468 DOI: 10.1073/pnas.96.4.1463.

529 Zadoks JC, Chang TT, Konzak CF. 1974. A decimal code for the growth stages of cereals. Weed

$530 \quad$ Research 14: 415-421. DOI: 10.1111/j.1365-3180.1974.tb01084.x 


\section{Table $\mathbf{1}$ (on next page)}

Summary of the model selection for each group.

Estimations are based on the calculated AICC value of the models, serving as the weight of evidence in favour of the different models. Most parsimonious models (delta $<2$ ) are marked in bold. 
Manuscript to be reviewed

\begin{tabular}{|c|c|c|c|c|c|c|}
\hline Group & models & df & logLik & AICc & delta & weight \\
\hline \multicolumn{7}{|c|}{ Pests and pathogens } \\
\hline \multirow[t]{5}{*}{ Aphids } & set-aside & 4 & -825.814 & 1659.7 & 0.00 & 0.735 \\
\hline & $\mathrm{pH}$ & 4 & -827.027 & 1662.2 & 2.43 & 0.218 \\
\hline & SOC & 4 & -829.284 & 1666.7 & 6.94 & 0.023 \\
\hline & landscape & 4 & -829.868 & 1667.8 & 8.11 & 0.013 \\
\hline & nitrogen & 4 & -830.014 & 1668.1 & 8.40 & 0.011 \\
\hline \multirow[t]{5}{*}{ Leaf spots } & landscape & 4 & -573.825 & 1155.8 & 0.00 & 0.728 \\
\hline & set-aside & 4 & -576.116 & 1160.3 & 4.58 & 0.074 \\
\hline & $\mathrm{pH}$ & 4 & -576.166 & 1160.4 & 4.68 & 0.070 \\
\hline & SOC & 4 & -576.217 & 1160.5 & 4.78 & 0.067 \\
\hline & nitrogen & 4 & -576.287 & 1160.7 & 4.92 & 0.062 \\
\hline \multicolumn{7}{|l|}{ Natural enemies } \\
\hline \multirow[t]{5}{*}{ Ground beetles } & $\mathrm{pH}$ & 4 & -286.264 & 580.9 & 0.00 & 0.422 \\
\hline & nitrogen & 4 & -286.910 & 582.2 & 1.29 & 0.221 \\
\hline & set-aside & 4 & -287.467 & 583.3 & 2.41 & 0.127 \\
\hline & landscape & 4 & -287.555 & 583.5 & 2.58 & 0.116 \\
\hline & SOC & 4 & -287.578 & 583.6 & 2.63 & 0.113 \\
\hline \multirow[t]{5}{*}{ Spiders } & landscape & 4 & -237.894 & 484.2 & 0.00 & 0.392 \\
\hline & soc & 4 & -238.766 & 485.9 & 1.74 & 0.164 \\
\hline & set-aside & 4 & -238.799 & 486.0 & 1.81 & 0.159 \\
\hline & nitrogen & 4 & -238.877 & 486.2 & 1.97 & 0.147 \\
\hline & $\mathrm{pH}$ & 4 & -238.937 & 486.3 & 2.08 & 0.138 \\
\hline \multicolumn{7}{|l|}{ Yield } \\
\hline \multirow[t]{5}{*}{ Ear mass } & set-aside & 4 & -221.817 & 452.1 & 0.00 & $>0.999$ \\
\hline & SOC & 4 & -249.092 & 506.6 & 54.55 & $<0.001$ \\
\hline & $\mathrm{pH}$ & 4 & -250.217 & 508.9 & 56.80 & $<0.001$ \\
\hline & nitrogen & 4 & -253.255 & 514.9 & 62.88 & $<0.001$ \\
\hline & landscape & 4 & -253.528 & 515.5 & 63.42 & $<0.001$ \\
\hline \multirow[t]{5}{*}{ Grain mass } & set-aside & 4 & -208.626 & 425.7 & 0.00 & $>0.999$ \\
\hline & SOC & 4 & -236.602 & 481.6 & 55.95 & $<0.001$ \\
\hline & $\mathrm{pH}$ & 4 & -237.652 & 483.7 & 58.05 & $<0.001$ \\
\hline & nitrogen & 4 & -240.399 & 489.2 & 63.55 & $<0.001$ \\
\hline & landscape & 4 & -240.777 & 490.0 & 64.30 & $<0.001$ \\
\hline
\end{tabular}




\section{Table 2 (on next page)}

Summary of the best models.

Coefficient and $z$ values correspond to average model, while estimated (beta), $t$ values and SD (random) are for the best models. Significant effects are in bold and directions of significant relationships (positive or negative) are designated by up and down arrows respectively. Marginal trends are underlined. Models' explanatory power tested by $R^{2}$ values and AICC. 


\begin{tabular}{|c|c|c|c|c|c|c|c|c|c|c|c|c|}
\hline Group & $\begin{array}{l}\text { Best } \\
\text { models }\end{array}$ & Variables & $\begin{array}{l}\text { Coefficient/ } \\
\text { estimated }\end{array}$ & SE & df & Z/t & $\mathbf{p}$ & & $\begin{array}{c}\text { SD } \\
\text { (random) }\end{array}$ & $\begin{array}{l}\text { marginal } \\
\mathrm{R}^{2} / \text { Fixed }\end{array}$ & $\begin{array}{l}\text { conditional } \\
\mathrm{R}^{2} / \text { Random }\end{array}$ & AICc \\
\hline \multicolumn{13}{|l|}{ Pests and } \\
\hline \multirow[t]{2}{*}{ Aphids } & Set-aside & intercept & 2.219 & 0.273 & 378 & 8.120 & $<0.001$ & & 0.872 & 0.113 & 0.276 & 1659.63 \\
\hline & & set-aside (with) & -1.464 & 0.448 & 19 & -3.267 & 0.004 & $\downarrow$ & & & & \\
\hline \multirow[t]{2}{*}{ Leaf spots } & Landscape & intercept & 0.762 & 0.147 & 361 & 5.195 & $<0.001$ & & 0.493 & 0.059 & 0.232 & 1155.65 \\
\hline & & landscape (simple) & -0.599 & 0.213 & 361 & -2.809 & 0.005 & $\downarrow$ & & & & \\
\hline \multicolumn{13}{|l|}{ Natural enemies } \\
\hline \multirow[t]{3}{*}{ Ground beetles } & Average & (intercept) & 1.374 & 4.654 & & 0.294 & 0.769 & & & 0.073 & 0.230 & 580.93 \\
\hline & & $\mathrm{pH}$ & 1.211 & $\underline{0.665}$ & & 1.706 & $\underline{0.088}$ & & & & & \\
\hline & & nitrogen (yes) & -0.881 & 0.725 & & 1.198 & 0.231 & & & & & \\
\hline \multirow[t]{4}{*}{ Spiders } & Average & (intercept) & 3.872 & 0.573 & & 6.673 & $<0.001$ & & & 0.015 & 0.098 & 484.16 \\
\hline & & landscape (simple) & -0.800 & 0.551 & & 1.360 & 0.174 & & & & & \\
\hline & & SOC & -0.350 & 0.569 & & 0.576 & 0.564 & & & & & \\
\hline & & set-aside (with) & 0.276 & 0.510 & & 0.507 & 0.612 & & & & & \\
\hline \multicolumn{13}{|l|}{ Yield } \\
\hline \multirow[t]{2}{*}{ Ear mass } & Set-aside & intercept & 17.531 & 0.589 & 78 & 29.759 & $<0.001$ & & 2.140 & 0.597 & 0.820 & 451.61 \\
\hline & & set-aside (with) & -7.034 & 0.715 & 78 & -9.832 & $<0.001$ & $\downarrow$ & & & & \\
\hline \multirow[t]{2}{*}{ Grain mass } & Set-aside & intercept & 15.127 & 0.485 & 78 & 31.166 & $<0.001$ & & 1.716 & 0.619 & 0.810 & 425.25 \\
\hline & & set-aside (with) & -6.202 & 0.615 & 78 & -10.075 & $<0.001$ & $\downarrow$ & & & & \\
\hline
\end{tabular}




\section{Figure 1}

The experimental plots (grey squares) were established next to the field margin.

The F+ (fertilizer added) designate fertilized subplots, while the F- (no fertilizer added) is for the control ones. Within an experimental plot (b), the locations of inventory transects are indicated by white rectangles and subplots for wheat harvesting with black ones.

A

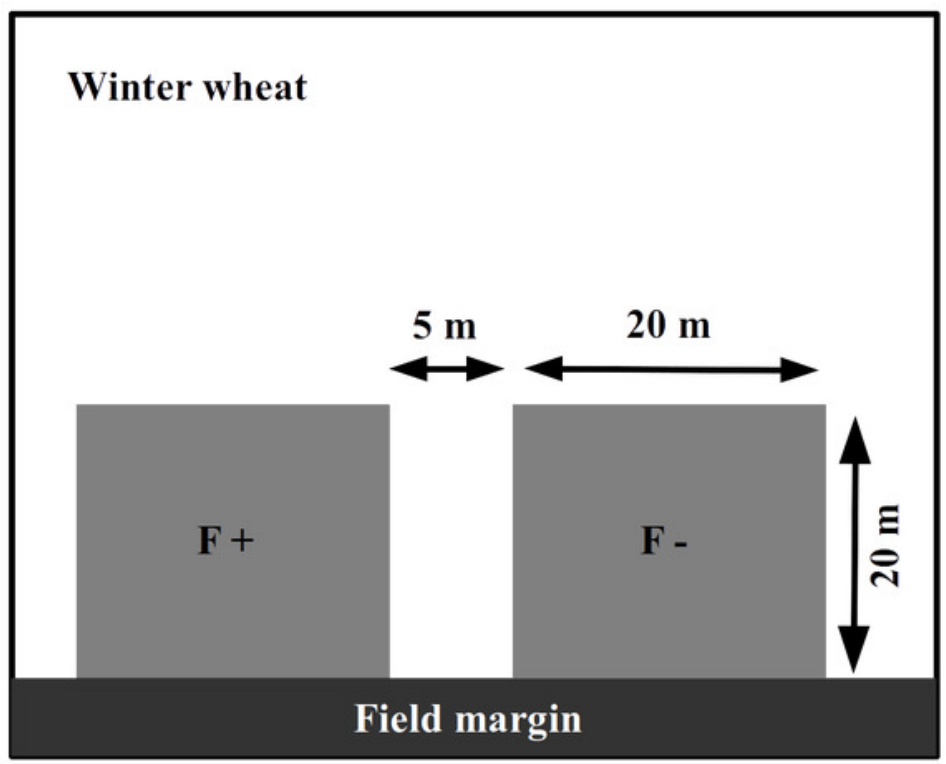

B

$20 \mathrm{~m}$

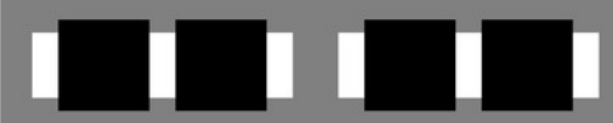

$10 \mathrm{~m}$

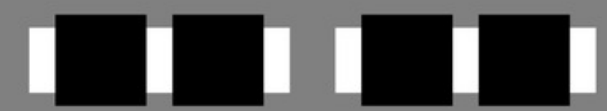

$5 \mathrm{~m}$

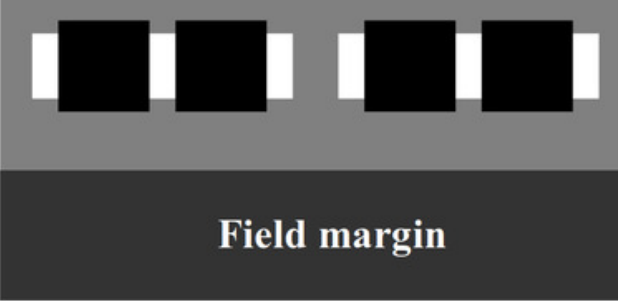




\section{Figure 2}

Response of aphid abundance (a), leaf spot prevalence (b) and winter wheat yield (c, d) to landscape configuration or complexity.

The yield was estimated by the ear $(\mathrm{c})$ and grain $(\mathrm{d})$ mass $\left(\mathrm{g} / \mathrm{m}^{2}\right)$. The portrayed values are means with whiskers representing 95\% confidence intervals. Different capital letters above indicate significant differences.

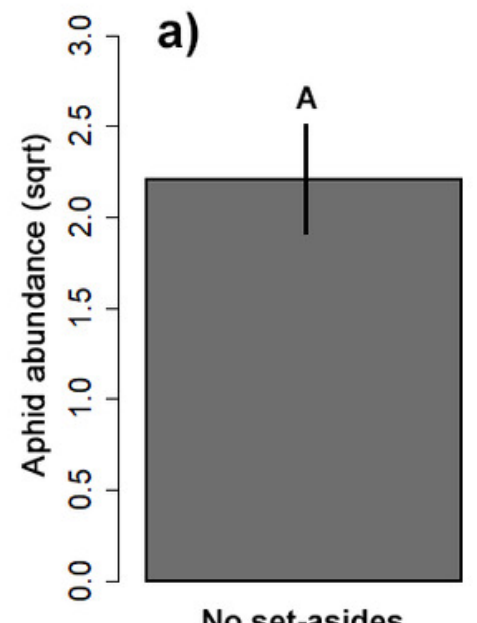

No set-asides

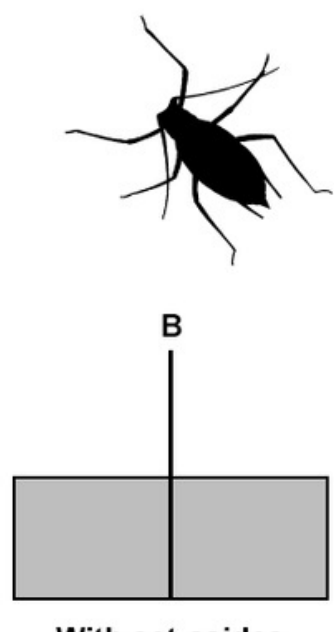

With set-asides Landscape configuration

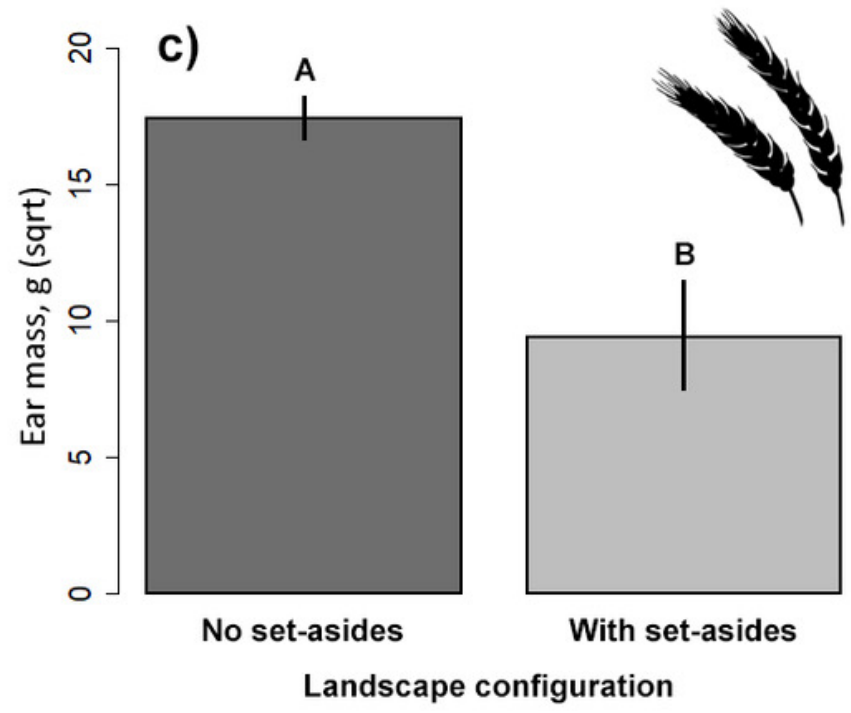

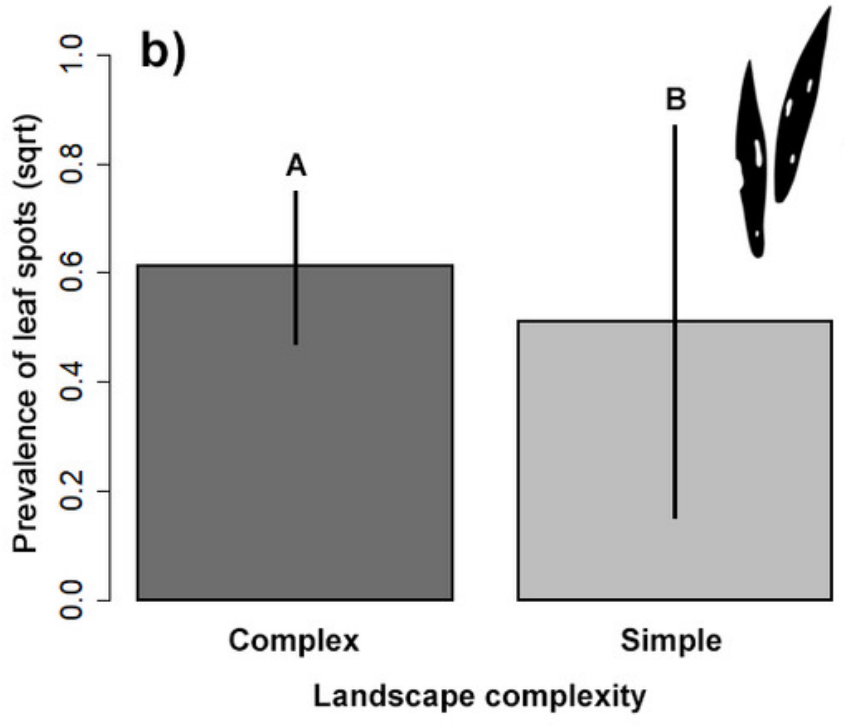

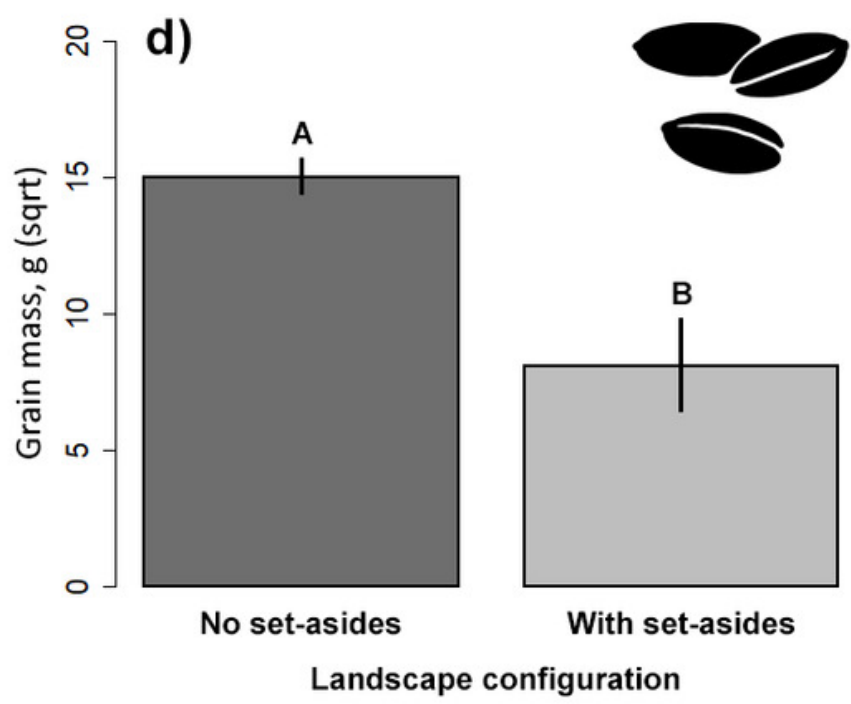


Figure 3

Response of the abundance for ground beetles $(a, b)$, and spiders (c, d) to landscape configuration and complexity.

The portrayed values are means with whiskers representing $95 \%$ confidence intervals. Different capital letters above indicate significant differences.

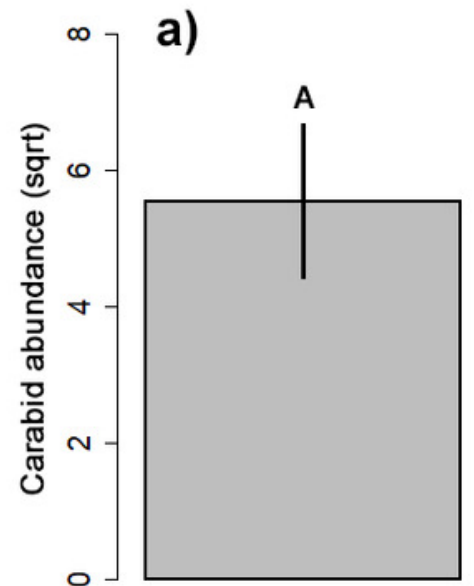

No set-asides

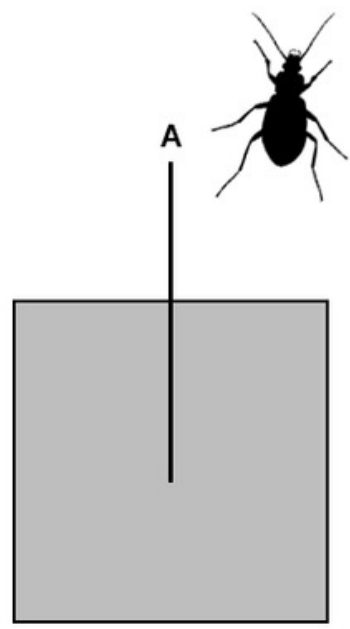

With set-asides

Landscape configuration

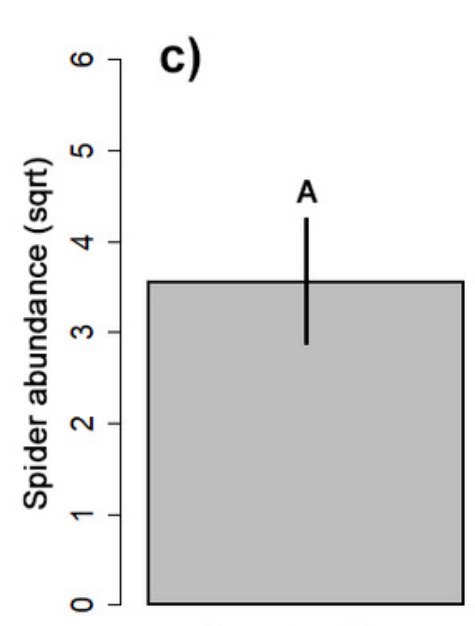

No set-asides

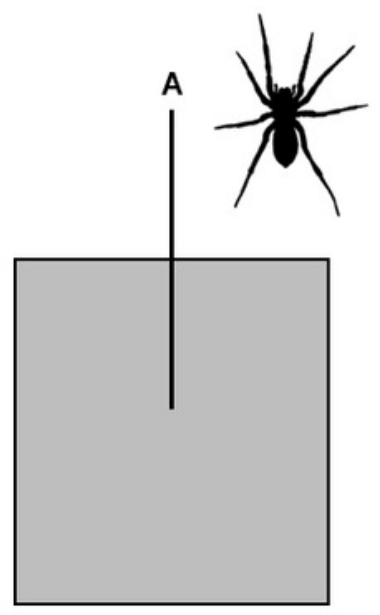

With set-asides Landscape configuration

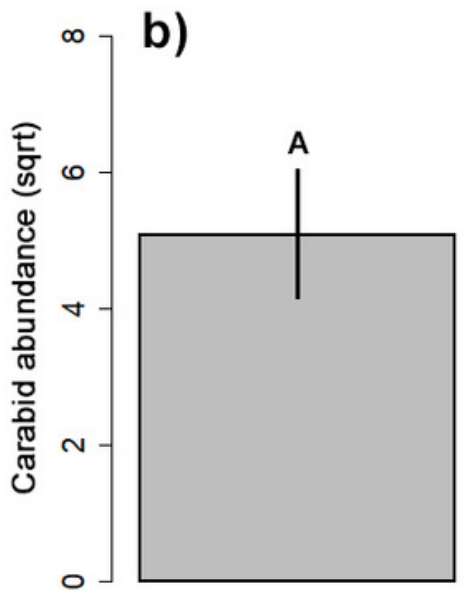

Complex

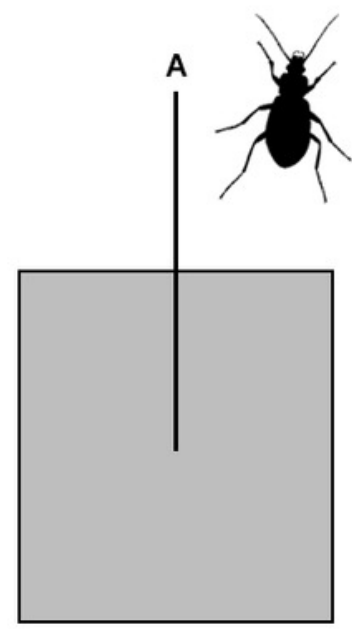

Simple
Landscape complexity

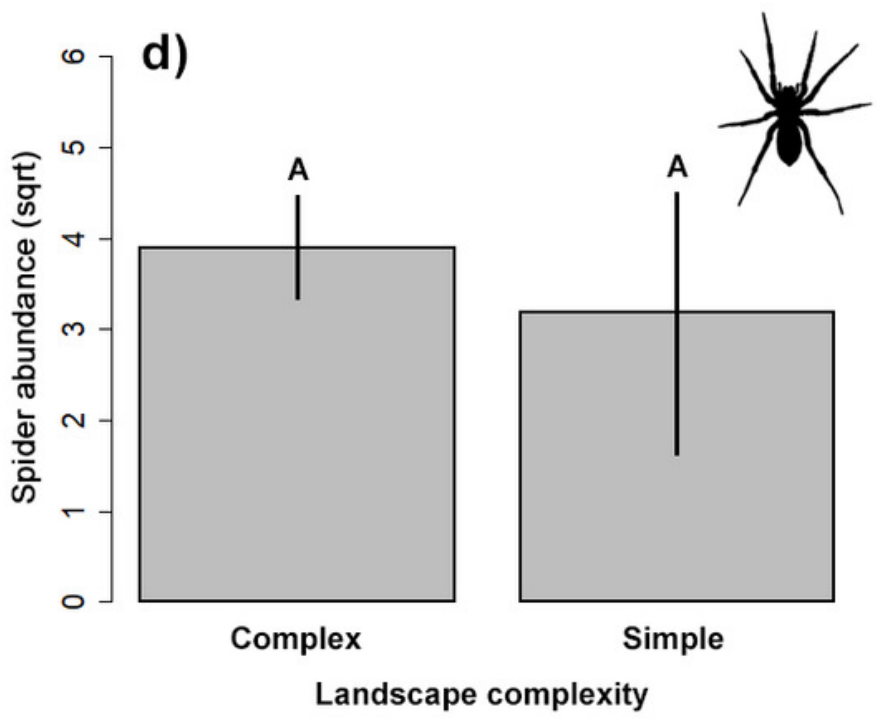

